UDK 630*411.16:595.78(497.6)

Original scientific paper

\title{
FIRST RECORD OF ENTOMOPATHOGENIC FUNGUS Entomophaga aulicae IN THE POPULATIONS OF BROWNTAIL MOTH IN BOSNIA AND HERZEGOVINA*
}

\author{
Mara TABAKOVIĆ-TOŠIĆ ${ }^{l}$, Marija MILOSAVLJEVIĆ ${ }^{1}$ \\ Sanja JOVANOVIĆl, Radovan LUČIĆ
}

\begin{abstract}
Browntail moth, is a well-known pest of broadleaf forests of Bosnia and Herzegovina. Although it is extremely polyphagous, it prefers to consume the leaves of various species of oaks. Browntail moth occurs periodically in high numbers (outbreak). Entomopathogenic fungus Entomophaga aulicae (Reichardt and Bail) Humber (Zygomycotina: Entomophtorales, Entomophtoraceae) is widespread Holarctic species, with many host insects from order Lepidoptera, where are some of the most economically harmful, outbreaking species of forest defoliators.

In sessile oak forests of eastern Bosnia and Herzegovina, the population density of browntail moth was determined by using route measurement during the growing season in the period 2015-2016. Browntail moth newly litters (40) were collected in four oak stands located in the region of Foča, Višegrad and Rogatica (PE Forests of the Republic of Srpska, Forest Estates Maglić, Panos and Sjemeć). In the litters, there were an average of 3,1 of dead old caterpillars and 4.7 pupae.The evaluation of E. aulicae infections was recorded as positive when hyphal bodies, primary conidia, or resting spores were detected on the surface of cadavers and puparia or in their tissues. The species identification was based on the size, shape and structural characteristics of different life forms of the fungus.

By the microscopical studies of the causes of the mortality of the browntail moth larvae and pupae, the presence of hyphal bodies, primary conidia and resting spores of the $E$. aulicae were confirmed in them. The dimension of the resting spores $(n=257)$ are $32.4-$ $48.5 \mu \mathrm{m}$, a.v. $44.1 \mu \mathrm{m}$, primary conidia $(n=54)$ 26.7-38.6 $\times 21.0-43.1 \mu \mathrm{m}$, a.v. 34.1-29.3 $\mu \mathrm{m}$. Hyphal bodies were not measured.
\end{abstract}

\footnotetext{
* Paper presented at International Congress on Invertebrate Pathology and Microbial Control (SIP-IOBC 2019), 28th July - 1st August, Valencija, Spain

${ }^{1}$ Institute of Forestry, Belgrade, Serbia

${ }^{2}$ Public Enterprise Forests of the Republic of Srpska, Banja Luka, Bosnia and Herzegovina
} 
As entomopathogenic fungus on two development stages of the host, larvae and pupae, presented results indicate that E. aulicae is a promising microbial control agent.

Key words: Euproctis chrysorrhoea, Entomophaga aulicae, epizootics, biological control

\section{PRVI NALAZ ENTOMOPATOGENE GLJIVE Entomophaga aulicae U POPULACIJAMA ŽUTOTRBE U BOSNI I HRECEGOVINI}

Izvod: Žutotrba, Euproctis chrysorrhoea (L.) (Lepidotera: Erebidae),dobro je poznata štetočina listopadnih šuma u Bosni i Hercegovini. Iako je izrazito polifaga, radije se hrani lišćem raznih vrsta hrastova. Povremeno se javlja u prenamnoženju (gradaciji). Entomopatogena gljiva Entomophaga aulicae (Reichardt and Bail) Humber (Zygomycotina: Entomophtorales, Entomophtoraceae) je široko rasprostranjena holarktička vrsta, sa velikim brojem domaćina - insekata iz reda Lepidoptera, među kojima su i pojedine ekonomski vrlo štetne, šumske, gradogene vrste defolijatora.

U području istočne Bosne i Hercegovine, u šumama hrasta kitnjaka, u periodu 2015-2016. godine, populaciona gustina žutotrbe je kontrolisana primenom maršrutnog metoda. Sa četiri ogledne površine u području Foče, Višegrada i Rogatice (JP Šume Republike Srpske, šumska gazdinstva Maglić, Panos i Sjemeć) obavljeno je uzorkovanje 40 (4 x 10) novoformiranih guseničijih gnezda. U gnezdima je bilo prosečno 3,1 uginula larva starijeg razvojnog stupnja i 4,7 lutki. Infekcija entomopatogenom gljivom E. aulicae beležena je kao pozitivna u slučajevima kada je na površini, ili u tkivima, uginulih gusenica i lutki, utvrđeno prisustvo hifa, primarnih konidija i trajnih spora. Identifikacija vrste zasnivala se na veličini, obliku i strukturnim karakteristikama navedenih životnih formi gljive.

Mikroskopskim istraživanjima uzroka smrtnosti larvi i lutki žutotrbe, potvrđeno je prisustvo hifa, primarnih konidija i spora E. aulicae. Pomoću posebnog programa obavljeno je njihovo merenje. Dimenzije trajnih spora $(n=257)$ su $32.4-48.5 \mu \mathrm{m}$, prosečno $44.1 \mu \mathrm{m}$,

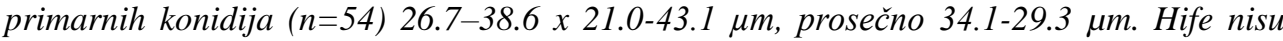
merene.

Kako je ustanovljeno da ova entomopatogena gljiva inficira dva razvojna stadija domaćina, larve i lutke, prezentovani rezultati pokazuju da je E. aulicae obećavajući mikrobiološki agens u sistemu klasične biološke borbe protiv žutotrbe. suzbijanje

Ključne reči: Euproctis chrysorrhoea, Entomophaga aulicae, epizoocija, biološko

\section{INTRODUCTION}

Browntail moth, Euproctis chrysorrhoea (Linnaeus, 1758) (Lepidotera: Erebidae), is a well-known pest of broadleaf forests of Central and Southern Europe. In the United States of America, it was introduced along with gypsy moth. Although it is extremely polyphagous and feeds on the leaves of most hardwood forest, fruit and ornamental trees, it prefers to consume the leaves of various species of oaks. Browntail moth occurs periodically in high numbers (outbreak) on a relatively small area of a few hundred hectares.

Naturally occuring entomopathogens are important regulatory factors in insect population. Entomopathogenic organisms, various types of viruses, microsporidia, bacteria, protozoa, fungi, nematodes, which can under favourable conditions cause massive insect mortality and are of great breeding capacity, 
normally live in nature. Epizootics caused by naturally occurring viral and fungal pathogens are often responsible for spectacular crashes of insect pest populations.

Entomopathogenic fungus Entomophaga aulicae (Reichardt and Bail) Humber (Zygomycotina: Entomophtorales, Entomophtoraceae) is widespread Holarctic species, with many host insects from order Lepidoptera, where are some of the most economically harmful, outbreaking species of forest defoliators [Lambdina fiscellaria Guenée, 1857; Choristoneura fumiferana (Clemens, 1865); Euproctis chrysorrhoea Linnaeus, 1758; Estigmene acrea (Drury, 1773)].

\section{MATERIAL AND METHODES}

In sessile oak forests of eastern Bosnia and Herzegovina, the population density of browntail moth was determined by using route measurement during the growing season in the period 2015-2016.

Brown tail moth newly litters (40) were collected in four oak stands (Table 1.) located in the region of Foča, Višegrad and Rogatica (PE Forests of the Republic of Srpska) (Picture 1.).

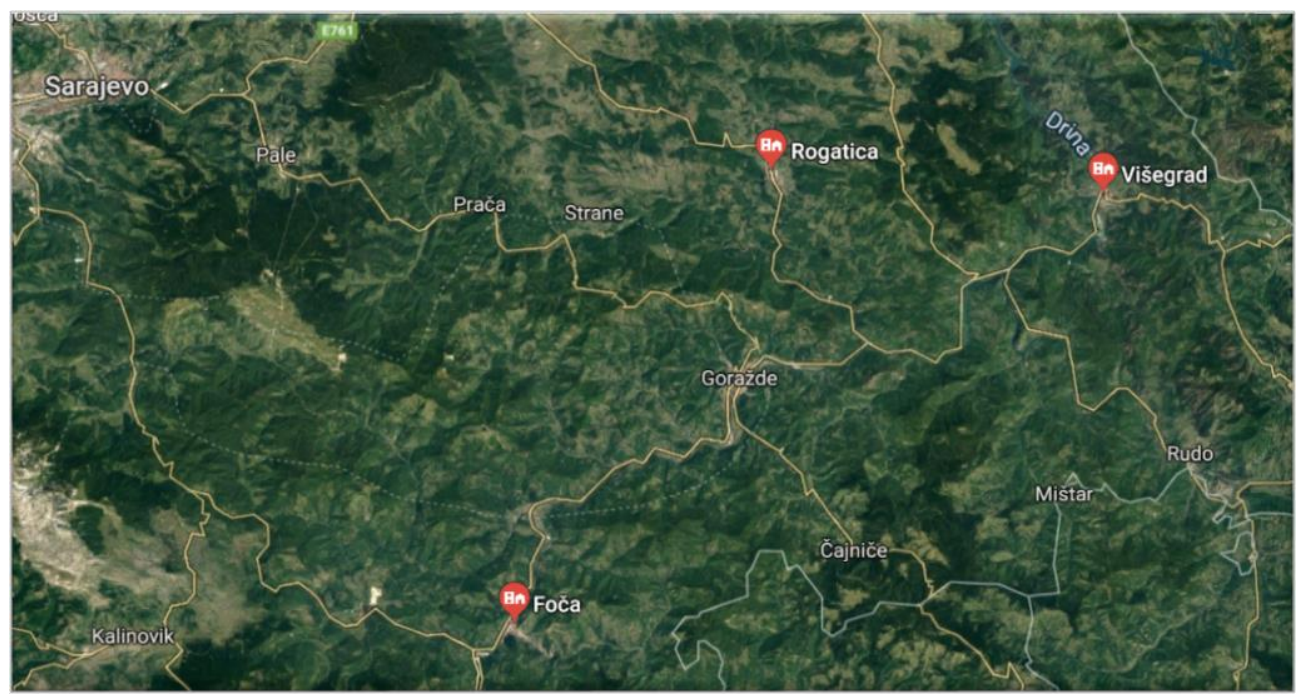

Picture 1. Google Map of the region of Foča, Višegrad and Rogatica

Table 1. The main characteristics of the sample plots

\begin{tabular}{|c|c|c|c|c|c|c|c|}
\hline \multirow[b]{2}{*}{ Plot } & \multirow[b]{2}{*}{$\begin{array}{l}\text { Forest } \\
\text { Estate }\end{array}$} & \multirow[b]{2}{*}{$\begin{array}{c}\text { Management } \\
\text { Unit }\end{array}$} & \multirow[b]{2}{*}{$\begin{array}{c}\text { Forest } \\
\text { Compartment }\end{array}$} & \multirow[b]{2}{*}{$\begin{array}{c}\text { Coordinates } \\
(\mathbf{X}, \mathbf{Y})\end{array}$} & \multirow[b]{2}{*}{$\begin{array}{l}\text { Altitude } \\
\text { (m) }\end{array}$} & \multicolumn{2}{|c|}{ Tipe of } \\
\hline & & & & & & Soil & $\begin{array}{c}\text { Sessile oak } \\
\text { forest }\end{array}$ \\
\hline 1 & \multirow{2}{*}{$\begin{array}{l}\text { Sjemeć } \\
\text { Rogatica }\end{array}$} & \multirow{2}{*}{ Gornja Prača } & 90 & $\begin{array}{lll}65 & 89 & 443 \\
48 & 43 & 203\end{array}$ & 815 & \multirow{2}{*}{$\begin{array}{l}\text { Deep acid } \\
\text { brown and } \\
\text { illimerised }\end{array}$} & High \\
\hline 2 & & & 112 & $\begin{array}{l}6590846 \\
4842043 \\
\end{array}$ & 830 & & $\begin{array}{l}\text { High and } \\
\text { coopice }\end{array}$ \\
\hline 3 & $\begin{array}{c}\text { Panos } \\
\text { Višegrad }\end{array}$ & $\begin{array}{c}\text { Sutjeska - } \\
\text { Radojna }\end{array}$ & 124 & $\begin{array}{l}6596702 \\
4842380 \\
\end{array}$ & 822 & $\begin{array}{c}\text { Euthric } \\
\text { brown and }\end{array}$ & \multirow{2}{*}{ Coopice } \\
\hline 4 & $\begin{array}{l}\text { Maglić } \\
\text { Foča }\end{array}$ & Slatina & 10 & $\begin{array}{l}6565092 \\
4818088\end{array}$ & 710 & $\begin{array}{c}\text { deep acid } \\
\text { brown }\end{array}$ & \\
\hline
\end{tabular}


The dead larvae and pupae from newly litters were placed in Petri dishes with wet filter paper. They were kept 7 days in the laboratory and then stored in the refrigerator. After the storage in the refrigerator for 3 months, the detailed microscope survey of the dead browntail moth caterpillars was done.

Microscopical examinations of diseased larvae and pupae were carried out using a MOTIC optical Trinocular, model Sextuple BA410E, equipped with a camera MOTICAM 10.0 (10 Mpix, 12.5 ", CMOS, MOTIC), and for processing the results of measurements of the hyphal bodies, primary conidia and resting spores (life forms) was used program Motic Images Plus 2.0 ML, gauging with the MT$40 \mathrm{X}$.

The evaluation of E. aulicae infections was recorded as positive when hyphal bodies, primary conidia, or resting spores were detected on the surface of cadavers and puparia or in their tissues. The species identification was based on the size, shape and structural characteristics of different life forms of the fungus.

\section{RESULTS AND DISCUSSION}

In the spring (May and June) 2015 and 2016 in the selected area in Rogatica (FE Sjemeć), Foča (FE Maglić) and Višegrad (FE Panos) regions (oak high and coppice forest stands in Management units Gornja Prača, Sutjeska Radojna and Slatina), the great increase of the population size of the browntail moth was reported.

In the 40 collected newly litters, there were an average of 3,1 of dead old caterpillars and 4.7 pupae. The detailed microscope survey showed in most of them the presence of the numerous resting spores of the entomopathogenic fungus $E$. aulicae. In addition, the presence of hyphal bodies and primary conidia of this pathogen species was reported, but the number of them was considerably smaller.

The dimension of the resting spores $(\mathrm{n}=257)$ are $32.4-48.5 \mu \mathrm{m}$, a.v. 44.1 $\mu \mathrm{m}$, primary conidia $(\mathrm{n}=54) 26.7-38.6$ x 21.0-43.1 $\mu \mathrm{m}$, a.v. 34.1-29.3 $\mu \mathrm{m}$ (Picture 2.). The morphological data correspond to descriptions given by MacLeod \& MüllerKögler (1973), Pilarska et al. (2001), Kalkar and Carner (2005), Keller and Petrini (2005) and Tabakovic-Tosic et al. (2018). Hyphal bodies were not measured.
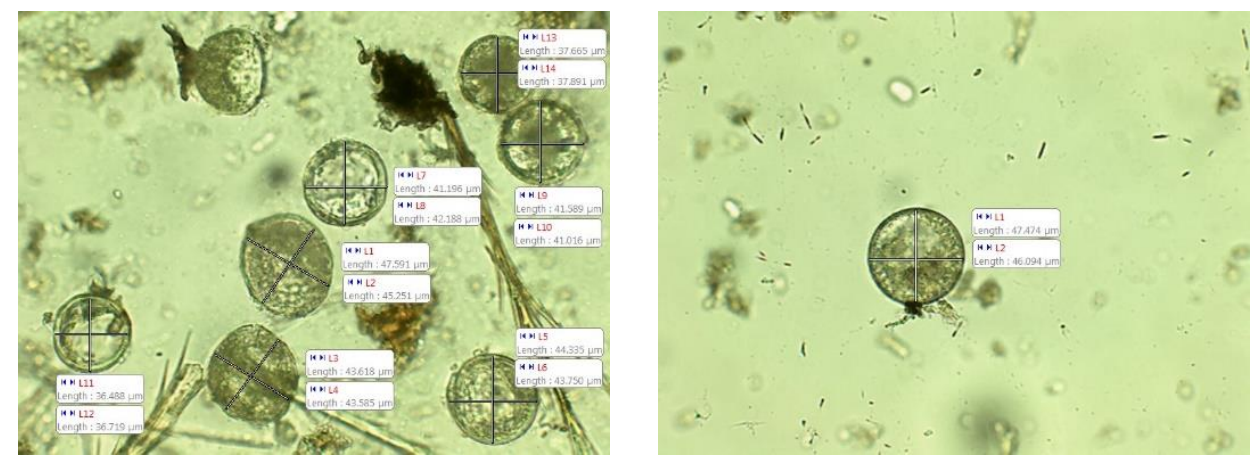

Picture 2. Resting spores isolated from dead larvae (FE Panos Višegrad, $M U$ Sutjeska-Radojna, FC 124) 


\section{CONCLUSION}

By the field and laboratory studies of the causes of the mortality of the older browntail moth larval instars the presence of hyphal bodies, primary conidia and resting spores of the entomopathogenic fungus $E$. aulicae were confirmed. It has been the first discovery of this kind in Bosnia and Herzegovina.

As entomopathogenic fungus on two development stages of the host, larvae and pupae, presented results indicate that E. aulicae is a promising microbial control agent.

The ability of this fungus to grow on artifical media make it worthy of further study for possible use in biological control - the artificial spread of pathogen. This method has advantages because only small amounts of the pathogen and inexpensive equipment for field application are needed.

\section{Acknowledgments}

The study was partly financed by the Minstry of Science of the Republic of Serbia, the Project 31070 - SUBPROJECT: New technological methods in the integral protection of forests with the focus on the entomopathogenic fungus Entomophaga maimaiga, as the possible solution to the problem of the frequent occurrences of the outbreak of gypsy moth in the forest ecosystems of Serbia.

\section{REFERENCES}

Kalkar, Ö. \& Carner, G. R. 2005: Characterization of the Fungal Pathogen, Entomophaga aulicae (Zygomycetes: Entomophthorales) in Larval Populations of the Green Cloverworm, Plathypena scabra (Lepidoptera: Noctuidae). Turkish Journal of Biology, 29: 243-248.

Keller, S. \& Petrini, O. 2005: Keys to the identification of the arthropod pathogenic genera of the families Entomophthoraceae and Neozygitaceae (Zygomycetes) with descriptions of three new subfamilies and new genus. Sydowia, 57(1): 23-53.

MacLeod, D. \& Müller-Kögler, E. 1973: Entomopathogenous fungi: Entomophthora species with pear-shaped to almost spherical conidia (Entomophthorales: Entomophthoraceae). Mycologia, 65: 823-893.

Pilarska D., Zimmermann G., Linde A., McManus M., Pilarski P., Takov D. 2001: On the occurrence of Entomophaga aulicae in high density browntail moth (Euproctis chrysorrhoea L.) populations in Bulgaria. In: Naydenova, T. et al. (Eds.). Proceedings of Third Balkan Scientific Conference 'Study, Conservation and Utilisation of forest Resources', 2-6 October 2001, Sofia, Bulgaria, Vol. III: 139-143.

Tabakovic-Tosic, M., Milosavljevic, M. \& Georgiev, G. 2018: Entomophaga aulicae (Reichardt in Bail) Humber (Entomophthorales: Entomophthoraceae), a New Entomopathogenic Fungus in the Republic of Serbia. Acta zoological bulgarica, 70(1): 133137. 